\title{
SISTEM PEMBERIAN KREDIT PEGAWAI DAN UMUM SEBAGAI UPAYA PENGENDALIAN INTERNAL PADA BPR Y
}

\section{Employee and General Credit Provision System as Internal Control Efforts at BPR Y}

\author{
Novya Nur Kasanah ${ }^{1}$ \\ nknovya@gmail.com \\ Program Studi Pendidikan Akuntansi/FKIP/Universitas PGRI Madiun \\ Jalan Setiabudi No. 85 Madiun (63118) \\ Isharijadi $^{2}$ \\ isharijadi57@gmail.com \\ Program Studi Pendidikan Akuntansi/FKIP/Universitas PGRI Madiun \\ Jalan Setiabudi No. 85 Madiun (63118) 2 \\ Nur Wahyuning Sulistyowati ${ }^{3}$ \\ nurwahyu@unipma.ac.id \\ Program Studi Pendidikan Akuntansi/FKIP/Universitas PGRI Madiun \\ Jalan Setiabudi No. 85 Madiun (63118) 3
}

\begin{abstract}
ABSTRAK
Penelitian ini bertujuan menganalisis sistem pemberian kredit untuk pegawai dan umum sebagai upaya pengendalian internal pada BPR Y. Jenis penelitian ini adalah penelitian deskriptif dengan pendekatan kualitatif yang dilakukan pada tahun 2019 dan melakukan wawancara pada Kabag Bisnis, Kasubag Kredit, Customer service dan SPI. Hasil penelitian menunjukkan bahwa secara umum sistem pemberian kredit sudah sesuai dengan kebijakan perkreditan dan SOP, hanya saja lembar checklist pada pengecekan berkas nasabah kredit tidak digunakan dan kunjungan pada nasabah dilakukan tidak terjadwal. Terkait pengendalian internal masih terdapat perangkapan tugas yang dilakukan oleh bagian IDEB sekaligus merangkap menjadi Kabag IT dan Pelaporan.
\end{abstract}

Kata Kunci: Kredit; Pegawai, Umum; Pengendalian Internal.

\section{ABSTRACT}

This study aims to analyze the system of lending to employees and the general public as an effort to control internal BPR $Y$. This type of research is a descriptive study with a qualitative approach conducted in 2019 and conducting interviews with the Head of Business, Head of Subdivision of Credit, Customer Service and SPI. The results of the study show that in general the lending system is in accordance with credit policies and SOPs, except that the checklist sheet on checking the credit customers' files is not used and visits to customers are not 
scheduled. Regarding internal control, there are still double tasks carried out by the IDEB section while concurrently becoming the Head of IT and Reporting.

\section{Keywords: $\quad$ Credit; Employee, Public; Internal Control.}

\section{PENDAHULUAN}

Bank menjadi salah satu instansi keuangan yang berperan penting dalam memenuhi kebutuhan masyarakat. Bank harus meminimalisir resiko yang kemungkinan terjadi, baik secara langsung maupun tidak karena saat ini usaha perbankan semakin meningkat. Pada BPR Y telah mengalami peningkatan jumlah kredit yang diberikan mulai tahun 2015 sampai dengan 2017. Di tahun 2016 ke tahun 2017, jumlah kredit bermasalah mengalami kenaikan yang cukup drastis yaitu dari $1,50 \%$ meningkat menjadi $4,90 \%$.

Undang - Undang Nomor 10 Tahun 1998 (1998) tentang Perbankan menjelaskan bahwa, bank merupakan badan usaha yang menghimpun dana masyarakat berupa simpanan dan menyalurkan kembali kepada masyarakat dalam bentuk pinjaman atau bentuk lainnya untuk meningkatkan taraf hidup rakyat banyak. Pemberian kredit atau pinjaman menjadi resiko yang paling dominan dalam kegiatan usaha bank karena memakai dana dari masyarakat yang sudah dipercayakan kepada bank. Tanpa adanya rasa kepercayaan maka kegiatan operasional bank tidak akan berjalan dengan semestinya. Sebelum pemberian kredit pada debitur, untuk memastikan bank bahwa debitur yakin, maka kreditur akan menentukan calon debitur yang layak mendapatkan pinjaman melalui calon debitur dengan prinsip kehati - hatian.

Pentingnya analisis calon debitur yaitu untuk menyelidiki keterangan, bukti, dan informasi penting serta relevan dalam pengambilan keputusan pemberian kredit. Kreditur harus memahami kondisi atau keadaan keuangan calon nasabah agar kreditur yakin bahwa pemberian kredit benar - benar aman dan mencegah timbulnya suatu resiko kredit. Peranan bank dan kesadaran debitur dalam pengembalian kredit menjadi salah satu faktor keberhasilan pemberian kredit oleh bank. Selain itu juga tidak terlepas dari penerapan prosedur dalam manajemen pemberian kredit kepada anggota dan masyarakat umum (Syafriansyah, 2015). 
Manajemen pemberian kredit yang kurang baik dan menghiraukan prinsip kehati - hatian akan mengakibatkan buruknya kinerja operasional bank. Sehingga bisa mempengaruhi kemajuan usaha bank. Oleh karena itu, perlu penetapan kebijakan dari supervisi kredit yang mendukung pengendalian kredit yang baik agar sistem dan prosedur mulai tahap pengajuan kredit sampai dengan pelunasan menjadi efektif dan terhindar dari terjadinya penyelewengan dalam permasalahan pemberian kredit (Lestari, Darminto, \& Topowijono, 2013).

Untuk memperkecil resiko dan kerugian yang dialami, bank harus memperhatikan manajemen dan sistem pengendalian internal terkait pemberian kredit. Penerapan pengendalian bukan untuk meniadakan semua kemungkinan terjadinya penyalahgunaan dan kekeliruan/penyelewengan, akan tetapi dapat meminimumkan terjadinya penyalahgunaan dan kekeliruan/penyelewengan dalam batas yang pantas. Pengendalian internal pemberian kredit yang efektif dan efisien dilakukan dengan mengamati lingkungan pengendalian, penaksiran resiko, informasi dan komunikasi, aktivitas pengendalian, dan pemantauan (Krismiaji, 2015).

Salim (2015) menjelaskan bahwa untuk pemahaman data dan informasi nasabah, maka pihak bank akan menetapkan prosedur - prosedur yang harus dilalui nasabah pengajuan kredit. Prosedur dalam pemberian kredit antara lain pengajuan berkas, penyelidikan berkas pinjaman, wawancara I, on the spot, wawancara II, keputusan kredit, penandatanganan akad, realisasi kredit dan penyaluran dana (Kasmir, 2015) tetapi ada perbedaan yaitu persiapan kredit, analisis kredit, keputusan kredit, pelaksanaan dan administrasi kredit, supervisi dan pembinaan debitur (Firdaus \& Arianti, 2011). Maka prosedur pemberian kredit yaitu permohonan kredit, penyelidikan dan analisis kredit, keputusan kredit, pencairan kredit dan pembinaan debitur.

Hindarto, AR, \& ZA (2014) menyebutkan bahwa kelancaran usaha, perolehan usaha, dan kesulitan operasi organisasi BPR akan menurun apabila penerapan pengendalian internal terhadap pemberian kredit utamanya kredit simpan pinjam masih kurang efektif yang diakibatkan masih lemahnya pencatatan piutang dengan belum adanya kartu utang bagi debitur. Sependapat dari hasil 
penelitian Topowijono \& Azizah (2015), perlu perbaikan untuk menambah dokumen keputusan penerimaan kredit dalam memaksimalkan pengendalian internal kredit konsumtif pada Koperasi Simpan Pinjam Bina Usaha Mandiri Kota Blitar. Sesuai dengan penjabaran tersebut, penelitian ini diperbarui karena adanya perbedaan lokasi penelitian, waktu penelitian, dan fokus penelitian pada pemberian kredit.

Penelitian ini bertujuan menganalisis sistem pemberian kredit untuk pegawai dan masyarakat umum sebagai upaya pengendalian internal pada BPR Y sehingga memberikan manfaat untuk mengetahui dan mengimplementasikan secara langsung ilmu akuntansi yang diperoleh khususnya pada mata kuliah perbankan dan sistem informasi akuntansi dan dapat mengetahui secara langsung sistem pemberian kredit untuk pegawai dan masyarakat umum dalam upaya pengendalian internal pada BPR Y. Selain itu, diharapkan dapat memberikan masukan untuk tambahan informasi bagi pihak bank mengenai peminimalisiran perangkapan tugas dan perbaikan dalam pengajuan kredit untuk pegawai dan masyarakat umum.

\section{METODE PENELITIAN}

Jenis penelitian ini adalah penelitian deskriptif dengan menggunakan pendekatan kualitatif karena memperoleh data berupa gambaran dengan kata kata serta menganalisis berbagai informasi yang didapatkan di lapangan kemudian disusun menjadi laporan penelitian yang mendetail. Penelitian dilakukan di BPR Y pada bulan Mei sampai dengan Juni 2019. Sumber data penelitian ini yaitu data primer dan sekunder melalui observasi, wawancara dan dokumentasi.

Data primer didapat melalui hasil wawancara dengan empat narasumber, yaitu Kabag Bisnis, Kasubag Kredit, Custtomer Service, dan SPI. Pemilihan informan tersebut sesuai dengan fokus penelitian untuk merespon rumusan masalah penelitian. Maka peneliti menentukan keempat narasumber tersebut karena beliau menjadi orang - orang yang berkaitan langsung dengan pemberian kredit untuk pegawai dan masyarakat umum serta pengendalian internal. Untuk 
data sekunder penelitian ini berupa catatan dan dokumen yang digunakan dalam pemberian kredit.

Teknik keabsahan data penelitian ini berupa uji credibility dengan triangulasi sumber dan teknik dengan alasan penggunaan waktu sehingga peneliti tidak menggunakan triangulasi waktu. Hal ini dikarenakan untuk triangulasi waktu memerlukan waktu yang lama untuk pengulangan wawancara sehingga memperlambat proses dokumentasi keterangan di lapangan.

\section{HASIL DAN PEMBAHASAN}

Analisis terhadap sistem pemberian kredit pegawai

Anasthasia, Darmawan, \& Werastuti (2015) menjelaskan bahwa pemberian kredit selalu menghadapi permasalahan, yaitu kemungkinan terjadinya kredit bermasalah yang menimbulkan tidak terjadi pengembalian kredit sehingga bank BRI mengalami kerugian finansial. Hasil penelitian menunjukkan bahwa pada BRI Unit Banyuasri untuk tiap pemberian kredit harus berdasarkan surat permohonan tertulis yang diotorisasi oleh pemohon. Permohonan tertulis dalam formulir permohonan kredit sesuai kriteria pada PT Bank Rakyat Indonesia (Persero), Tbk Banyuasri.

Prosedur dalam pemberian kredit pegawai yang diberikan pada BPR Y dimulai dengan calon nasabah datang pada BPR pusat ataupun kantor kas dan meminta formulir permohonan kredit yang diinginkan. Berikut penjelasan pemberian kredit pegawai di BPR Y. (1) Tahap permohonan kredit yang menjadi tahap awal calon debitur harus mengisi persyaratan yang sudah ditentukan, seperti mengisi formulir permohonan kredit, mengisi surat kuasa potong gaji dan berkas berkas lain yang mendukung dalam pengajuan kredit. Apabila sudah lengkap, maka bagian customer services akan menuliskan pendaftaran pengajuan kredit pada buku register yang kemudian diserahkan pada bagian IDEB (Informasi Debitur). Akan tetapi dalam memeriksa berkas nasabah, BPR Y belum menggunakan lembar checklist secara maksimal, seperti tidak digunakan dalam pengecekan berkas pengajuan nasabah. Hal ini mengakibatkan bagian account officer (AO) melakukan cek ulang berkas nasabah. (2) Analisis Kredit. 
Analisis kredit dilakukan seteleh pengecekan BI checking. BI checking ini dilakukan oleh bagian IDEB yang selanjutnya membuat memo data pinjaman nasabah pada bank lain dan selanjutnya semua berkas dilimpahkan pada bagian account officer (AO) untuk melakukan analisis. Account officer (AO) pegawai bertugas menganalisis terhadap pengajuan kredit yang diajukan oleh calon nasabah pegawai. Seorang AO harus memiliki kemampuan dalam menganalisis data saat melakukan on the spot. Pengumpulan data harus sesuai dengan permohonan persyaratan dan memiliki prinsip kehati - hatian dalam menganalisis dan nantinya dari analisis tersebut dibuat suatu laporan hasil dari pemeriksaan account officer (AO) dan diserahkan pada bagian komite kredit untuk keputusan kredit terakhir. (3) Keputusan Kredit.

Keputusan kredit dilakukan oleh suatu team dalam proses pengambilan keputusan kredit. Dalam putusan kredit terdapat dua kemungkinan yang akan terjadi, yaitu disetujui dan tidak disetujui pemberian kredit. Keputusan kredit ini harus sesuai dengan ketentuan yang berlaku. Apabila pengajuan kredit tersebut ditolak maka AO akan menyampaikan surat atau telepon atas penolakan pengajuan kredit. Seluruh berkas dan dokumen pemberian kredit diberikan kepada bagian administrasi untuk dikembalikan kepada calon debitur. Dan apabila pengajuan disetujui maka akan dilanjutkan pada tahap berikutnya. (4) Penarikan/pencairan kredit.

Penarikan/pencairan kredit dilakukan apabila administrasi nasabah sudah lengkap dan ditujui oleh pihak terkait. Akad kredit akan dijelaskan pihak bank agar nantinya calon debitur memahami isi dari akad kredit tersebut yang akan ditandatangani apabila calon debitur merasa keberatan, maka calon debitur berhak membatalkan pengajuan kredit tersebut. Administrasi ini menjadi bukti bahwa pengajuan kredit dari nasabah telah disetuji dan sudah melakukan pengajuan sesuai dengan aturan bank. Pencairan kredit ini dilakukan di bagian teller dan membuatkan kwitansi tanda terima uang yang akan diberikan kepada nasabah dan sebagai arsip pihak bank. (5) Monitoring kredit.

Monitoring kredit dilakukan setelah satu bulan pencairan kredit. Biasanya yang dipantau yang tergolong kredit bermasalah dan tidak terjadwal untuk kredit 
yang lancar. Monitoring ini dilakukan oleh AO setelah itu pimpinan biasanya menginstruksikan disposisi ke bagian kasubag bisnis.

Prosedur tersebut didukung dari pernyataan Customer Service yang menyatakan bahwa:

"Nanti nasabah datang kita memberikan informasi keperluan apa yang dibutuhkan. Kalau di kita kan terkait dengan masalah tabungan bisa, deposito dan pengajuan kredit. Tergantung dari nasabahnya mau pengajuan kredit pegawai ataupun swasta. Kredit pegawai persyaratannya seperti pada umumnya yaitu fotocopy KTP suami istri, fotocopy $K K$, fotocopy gaji struk terakhir dan tanda tangan yang ada pada permohonan kredit dari dinas terkait."

Senada dengan pernyataan dari Kasubag Kredit:

"Nasabah datang ke kantor langsung ke CS dulu kemudian CS mencatat nomer registrasi nama nasabah tersebut kemudian dari CS itu nanti menyerahkan ke bagian pegawai (AO) dan dilanjut tahap keputusan kredit. Yang mana dalam putusan kredit ada kemungkinan yaitu disetujui atau ditolak. Dari AO nanti menganalisis sesuai dengan permohonan persyaratan dan semua memakai prinsip kehati

- hatian. Jadi itu memang harus kita terapkan di dunia perbankan."

Selain itu juga didukung dari hasil penelitian Putra, Rahayu, \& Saifi (2016), bahwa sistem dan prosesur pemberian kredit diawali dangan permohonan kredit oleh nasabah kemudian dianalisis oleh Kasi Kredi yang dilanjutkan diajukan pada pimpinan cabang apabila data sudah lengkap. Setiap nasabah harus melewati proses - proses pemberian kredit yang sudah ditetapkan oleh bank karena syarat untuk memproleh fasilitas kredit tersebut dan tahapan dalam pemberian kredit membutuhkan informasi yang berbeda dari nasabah yang terlibat (Saputra, Zukhri, \& Indriyani, 2014). Pemberian kredit pegawai ini merupakan salah satu fasilitas kredit yang diberikan oleh BPR Y yang mana kredit ini diperuntukkan pada pegawai instansi pemerintahan kota dengan agunan pemotongan gaji sehingga untuk pembayaran kredit dengan sistem angsuran potong gaji.

Analisis terhadap sistem pemberian kredit masyarakat umum

Prosedur pemberian kredit untuk masyarakat umum yang diberikan pada BPR Y tidak jauh berbeda dengan pemberian kredit untuk pegawai. Hanya saja yang membedakan pada surat kuasa jaminan. Untuk kredit pegawai surat kuasa 
berupa potong gaji dan untuk kredit masyarakat umum berupa jaminan $\mathrm{BPKB} /$ sertifikat bangunan.

Prosedur pemberian kredit untuk masyarakat juga dimulai dengan calon nasabah datang pada BPR pusat ataupun kantor kas dan meminta formulir permohonan kredit yang diinginkan. Berikut penjelasan pemberian kredit pegawai di BPR Y. (1) Tahap permohonan kredit menjadi tahap awal calon debitur harus mengisi persyaratan yang sudah ditentukan, seperti mengisi formulir permohonan kredit, mengisi surat kuasa jaminan dan berkas - berkas lain yang mendukung dalam pengajuan kredit. Apabila sudah lengkap, maka bagian customer services akan menuliskan pendaftaran pengajuan kredit pada buku register yang kemudian diserahkan pada bagian IDEB. Akan tetapi dalam memeriksa berkas nasabah, BPR Y belum menggunakan lembar checklist secara maksimal seperti tidak digunakan dalam pengecekan berkas pengajuan nasabah. Hal ini mengakibatkan bagian account officer (AO) melakukan cek ulang berkas nasabah. (2) Analisis Kredit.

Analisis kredit dilakukan seteleh pengecekan BI checking. BI checking ini dilakukan oleh bagian IDEB yang selanjutnya membuat memo data pinjaman nasabah pada bank lain dan selanjutnya semua berkas dilimpahkan pada bagian account officer (AO) untuk melakukan analisis. Account officer (AO) umum bertugas menganalisis pengajuan kredit untuk masyarakat umum. Pada BPR Y, bagian AO pegawai dan AO umum dibagi secara terpisah agar tanggung jawab dalam analisis kredit tidak tercampur jadi satu. Seorang AO harus memiliki kemampuan dalam menganalisis data saat melakukan on the spot. Pengumpulan data harus sesuai dengan permohonan persyaratan dan memiliki prinsip kehati hatian dalam menganalisis dan nantinya dari analisis tersebut dibuat suatu laporan hasil dari pemeriksaan account officer (AO) dan diserahkan pada bagian komite kredit untuk keputusan kredit terakhir. (3) Keputusan Kredit.

Keputusan kredit dilakukan oleh suatu kelompok dalam proses pengambilan keputusan kredit. Dalam putusan kredit terdapat dua kemungkinan yang akan terjadi, yaitu disetujui dan tidak disetujui pemberian kredit. Keputusan kredit ini harus sesuai dengan ketentuan yang berlaku. Apabila pengajuan kredit 
tersebut ditolak maka AO akan menyampaikan surat atau telepon atas penolakan pengajuan kredit. Seluruh berkas dan dokumen pemberian kredit diberikan kepada bagian administrasi untuk dikembalikan kepada calon debitur. Dan apabila pengajuan disetujui maka akan dilanjutkan pada tahap berikutnya. (4) Penarikan/pencairan kredit.

Penarikan/pencairan kredit dilakukan apabila administrasi nasabah sudah lengkap dan disetujui oleh pihak terkait. Akad kredit akan dijelaskan pihak bank agar nantinya calon nasabah kredit mengerti maksud dari akad kredit tersebut yang akan ditandatangani apabila calon penerima kredit merasa keberatan, maka berhak membatalkan pengajuan kredit tersebut. Administrasi ini menjadi bukti bahwa pengajuan kredit dari nasabah telah disetujui dan sudah melakukan pengajuan sesuai dengan aturan bank. Pencairan kredit ini dilakukan di bagian teller dan membuatkan kwitansi tanda terima uang yang akan diberikan kepada nasabah dan sebagai arsip pihak bank. (5) Monitoring kredit.

Monitoring menjadi kondisi yang utama karena merupakan hal yang beresiko bagi bank. BPR Y melakukan on the spot hanya 2 kali. Yang pertama dari AO untuk menganalisis pengajuan kredit dan yang kedua pada saat terjadinya kredit bermasalah yang mana biasanya pimpinan menginstruksikan disposisi ke bagian kabag bisnis. Berikut kutipan wawancara dari kasubag kredit bahwa:

"On the spot kita melakukannya 2 kali. Jadi yang pertama itu dari AO setelah itu pimpinan biasanya menginstruksikan disposisi ke bagian kasubag bisnis. Pemantauan itu mesti dilakukan setelah satu bulan pencairan dan bisa dibilang setiap hari selalu dipantau. Biasanya yang dipantau yang tergolong bermasalah mbak."

Kondisi tersebut didukung juga hasil penelitian Sa'adah, Dwiatmanto, \& Husaini (2015) bahwa pelaksanaan monitoring atau on the spot dilakukan tidak terlalu sering pada semua nasabah kredit dan hanya dilakukan pada awal nasabah mendapatkan kredit dan saat mengalami penundaan pembayaran angsuran. On the spot atau pengamatan langsung ke tempat usaha nasabah sewajarnya dilakukan secara terjadwal paling tidak satu bulan sekali dan lebih efektif apabila pihak bank tidak menginfokan kepada nasabah sehingga tidak terjadi kecurangan yang dilakukan nasabah (Fauza, Saifi, \& Dwiatmanto, 2016). 
Prosedur pemberian kredit untuk masyarakat umum tersebut sesuai dengan hasil wawancara dengan kasubag kredit bahwa:

"Nasabah kan datang ke pusat. Dari pusat itu nanti nasabah datang ke CS nanti CS meregistrasi dan CS menyerahkan berkas ke masing - masing kas sesuai alokasi. Tahap selanjutnya nanti setelah dikasihkan ke alokasi kas masing - masing nanti dari pihak kas melakukan analisis. Sebelum analisis dilakukan SID dulu atau BI checking dulu setelah itu dilihat kira - kira BI checkingnya bagaimana kalau BI checkingnya bagus nanti lanjut ke tahap pemeriksaan.Kemudian ke tahap putusan. Nanti kalau diacc otomatis langsung akad kredit saja dilanjutkan pencairan dan melakukan penandatanganan akad sebagai persyaratan administrasi. Kalau kredit umum itu kan harus pakai jaminan diantaranya sertifikat maupun BPKB."

Pernyataan tersebut didukung dengan pernyataan dari kabag bisnis:

"Permohonan diterima CS kemudian dialokasikan ke daerah alamat nasabahnya kalo alamat terdekat di kas mana dikasihkan di kas tersebut. Kemudian dari pegawainya yang di kas melakukan survei ke lapangan biasanya AO kemudian sampai kantor dibuatkan analisa pelaporan pemeriksaan seperti apa. Untuk dokumen nasabahnya antara lain fotocopy jaminan bisa BPKB/STNK terakhir, gesek rangka mesin, nomer rangka, kemudian kalau sertifikat ya fotocopy sertifikatnya."

Demikian juga dari hasil penelitian Tawaqal, Sudjana, \& Yaningwati (2016) menunjukkan prosedur pemberian kredit dimulai dengan tahap permohonan kredit oleh debitur sesuai persyaratan yang dibuat pihak kreditur. Apabila sudah dipenuhi sesuai ketentuan kemudian diverifikasi administrasi dan pengelompokkan pembiayaan kredit. Tahap selanjutnya hasil verifikasi akan diajukan kepada bagian analisis kredit untuk persetujuan.

Analisis terhadap pengendalian internal dalam sistem pemberian kredit pegawai dan masyarakat umum

Manajemen kredit yang efektif dan efisien dan implementasi pengendalian yang baik menjadi faktor untuk mencapai hasil yang maksimal. Pengendalian internal yang memadai pada dasarnya bermanfaat untuk mengamankan kepemilikan harta organisasi dengan meminimalisir kemungkinan terjadinya penyalahgunaan, penggelapan, kredit macet, serta meningkatkan ketepatan dan efektivitas kerja (Sesiady, AR, \& Saifi, 2018). Hasil penelitian Anasthasia et al. (2015) juga menjelaskan bahwa unsur - unsur sistem pengendalian intern pada PT. 
Bank Rakyat Indonesia (Persero), Tbk Unit Banyuasri cukup baik karena sudah ada pembedaan tugas dan kewenangan dalam struktur organisasi, serta praktik yang sehat dalam melakukan fungsi setiap unit organisasi. Akan tetapi tetap ada kelemahan atau kekurangan dalam penerapan sistem dan prosedur pemberian kredit (Sandi, Dwiatmanto, \& A, 2015).

Kondisi ini bertolak belakang dengan temuan dari hasil wawancara berkaitan dengan pemberian kredit untuk pengendalian internal masih terdapat penggandaan tugas yang dilakukan oleh bagian IDEB yang merangkap menjadi Kasubag IT dan Pelaporan. Berikut pernyataan dari bagian SPI:

"Perangkapan tugas di sini ada. Karena sesuai dengan ketentuan baru dari Otoritas Jasa Keuangan ada bagian - bagian atau jabatan baru yang wajib diisi namun secara tugas dan fungsinya belum begitu dibutuhkan. IDEB itu kebetulan yang dulu diberangkatkan pelatihan dan dibutuhkan di lapangan tapi cenderung dilakukan oleh IT."

Lingkungan Pengendalian

Peneliti menilai bahwa lingkungan pengendalian yang ada di BPR Y sudah berjalan efektif. Hal ini ditandai dengan adanya semua karyawan di BPR Y sudah menanamkan nilai etika dan memiliki intergritas yang tinggi dalam melakukan setiap pekerjaannya. Jadi setiap pegawai dituntut untuk melakukan pekerjaannya dengan penuh tanggungjawab dan kejujuran. Manajer setiap bagian selalu memberikan cerminan ide, arahan, maupun evaluasi terhadap karyawan karyawannya agar bisa dijadikan standar pengukuran dalam perbaikan di masa yang akan datang. Untuk meningkatkan kemampuan dan pengetahuan karyawan dapat memberikan bekal pendidikan dan pelatihan kepada karayawan (Sa'adah, 2015). Untuk struktur organisasi di BPR Y sudah diperbarui sesuai dengan ketentuan terbaru. Kalaupun nasabah telah mengalami kredit yang bermasalah, maka karyawan segera konfirmasi dan mengingatkan nasabah untuk membayar kredit tersebut. Jika mengingatkan tidak mempan maka melakukan panggilan nasabah ke kantor untuk diberi pengertian bahwa kalau nasabah pengajuan kredit berarti mereka membutuhkan dana sehingga pihak bank menginginkan tanggung jawab dari nasabah. Hal ini didukung dari pernyataan kasubag kredit bahwa: 
"Kalaupun ada nasabah yang tidak tepat itu kita ukur dengan ukuran bulan bukan ukuran tanggal. Katakanlah kalau nasabah itu bayar tepat tanggal itu kadang ada molornya. Jadi kita mengupayakan ke nasabah itu bayar tidak tepat waktu ya kita ingatkan. Jika mengingatkan itu tidak mempan lagi kita melakukan panggilan nasabah ke kantor kemudian kita kasih pengertian bahwa kalau nasabah itu pengajuan kredit berarti dia butuh sedangkan kita sudah memberikan itu ya ada timbal baliknya"

Selain itu juga didukung dari hasil penelitian Salim (2015) bahwa karyawan harus segera menginformasikan pada bagian pembinaan apabila ada nasabah yang menunjukkan gelagat dalam tunggakan pembayaran kredit agar diawasi tempo pembayaran angsuran berupa tindakan tegas atau surat peringatan.

Penaksiran resiko

Dalam pemberian kredit salah satunya apabila usaha nasabah mengalami kepailitan sehingga tidak dapat menyelesaikan angsuran yang sudah ditetapkan. Hal ini menjadi salah satu resiko kedepan yang harus dihadapi pihak bank sehingga perlu dilakukan penyelamatan agar bank tidak mengalami kerugian. Hal ini didukung dari pernyataan kabag bisnis bahwa:

"Kendala secara umum tidak ada. Mungkin satu atau dua nasabah yang dulunya usahanya baik - baik saja tiba - tiba pailit sehingga harus dilakukan penyelamatan. Apabila sudahtidak bisa diselamatkan, maka terpaksa kita ganti karena agunannya sudah kuat dengan pengikatan tersebut"

Informasi dan Komunikasi

Berdasarkan informan 4 bahwa informasi komunikasi pada BPR Y diolah dan digunakan secara baik melalui sistem yang ditetapkan oleh BPR Y. Semua data dan dokumen - dokumen terkait pemberian kredit disimpan secara sistematis di bagian operasional. Hasil penelitian Papalangi (2013) bahwa pengarsipan dokumen pemebrian dilakukan secara runtut, disimpan pada brankas tahan api di ruang khusus dan terkomputerisasi dengan baik mulai dari permohonan kredit sampai likuidasi kredit. Hal ini sesuai dengan hasil wawancara pada kabag bisnis:

"Untuk penyimpanan dokumen fisiknya itu di bagian operasional baik itu fisik agunan ataupun fisik SPK."

Aktivitas Pengendalian

Dalam setiap aktivitas yang ada di BPR Y selalu diotorisasi oleh pihak terkait untuk pemberian kredit terdapat komite kredit dalam otorisasi dokumen. 
Dokumen - dokumen fisik agunan ataupun SPK dari nasabah akan disimpan di bagian operasional karena untuk keperluan bukti dalam mekanisme audit.

Pemantauan kinerja

Pemantauan kinerja atau monitoring yang dilakukan BPR Y belum sesuai karena pemantauan hanya dilakukan oleh bagian umum/SDM dan hanya dilakukan setiap bulan. Selanjutnya, SPI memiliki wewenang apabila ada sesuatu yang tidak sesuai SOP nantinya dilakukan tindakan berupa catatan temuan untuk dilaporkan dan ditindaklanjuti oleh direksi. Pemeriksaan independen terkait kinerja karyawan dilakukan dengan cara melihat kedisiplinan karyawan saat hadir di kantor. Untuk bulan - bulan lalu, dalam monitoring kinerja karyawan masih menggunakan manual, yaitu mulai dari absensi kehadiran, kedisiplinan jam pulang, dan jam masuk kerja namun, saat ini sudah menggunakan sistem KPI untuk menilai kinerja karyawan kemudian dibuat laporan evaluasi monitoring kinerja setiap bulan. Namun pada BPR Y masih ditemukan adanya perangkapan tugas yang dilakukan salah satu bagian yaitu bagian IDEB merangkap bagian IT dan Pelaporan.

\section{KESIMPULAN DAN SARAN}

Berdasarkan dari pembahasan dan analisis penelitian yang telah dilakukan pada sistem pemberian kredit pegawai dan masyarakat umum sebagai upaya pengendalian internal pada BPR Y maka disimpulkan bahwa sistem pemberian kredit secara umum telah sesuai dengan apa yang dijelaskan pada Pedoman Kebijakan Perkreditan yang dibuat oleh BPR Y, dan Pedoman Kebijakan Perkreditan tersebut sesuai dengan ketentuan Otoritas Jasa Keuangan. Selain itu, BPR Y telah didukung dengan adanya fungsi Satuan Pengawas Intern (SPI) yang memiliki tugas memonitor semua kegiatan yang terjadi di BPR Y dan untuk melakukan perbaikan jika memang ada sesuatu yang harus diperbaiki. Namun, ada beberapa hal yang harus dibenahi untuk mewujudkan pengendalian internal yang memadai dan efisiensi kerja, antara lain: (1) dalam memeriksa kelengkapan berkas pengajuan permohonan kredit, CS tidak menggunakan lembar ceklist yang mana nantinya bisa saja petugas tersebut lalai akan berkas - berkas yang sudah 
dipenuhi oleh calon debitur, (2) adanya penggandaan misi yang dilakukan oleh bagian IDEB yang merangkap dengan bagian Kasubag IT dan Pelaporan, dan (3) review dokumen dan kunjungan nasabah atau on the spot yang dilakukan tidak terjadwal dan baru terjadwal jika memang tergolong dalam kredit bermasalah.

Keterbatasan dalam penelitian ini yaitu tidak didapatnya informasi dari nasabah pengguna kredit untuk pegawai maupun masyarakat umum, sehingga peneliti tidak dapat menguraikan secara spesifik bagaimana penggunaan fasilitas pemberian kredit pada nasabah. Selain itu, dalam observasi tidak bisa dilakukan secara keseluruhan hanya sampai permohonan kredit saja karena keterbatasan waktu dan dokumen tidak bisa diperoleh menyangkut kerahasiaan bank. Untuk penelitian selanjutnya, agar memperoleh informasi dari nasabah kredit untuk memperkuat hasil penelitian. Observasi juga harus dilakukan semaksimal mungkin seperti mulai dari permohonan kredit hingga pembinaan debitur (kunjungan nasabah) untuk mengetahui dokumen dan bagian terkait permohonan kredit hingga pembinaan debitur.

\section{DAFTAR PUSTAKA}

Anasthasia, D. D., Darmawan, N. A. S., \& Werastuti, D. N. S. 2015. Analisis Sistem Pengendalian Intern dalam Pemberian Kredit Mikro Pada PT . Bank Rakyat Indonesia ( Persero ), Tbk Unit Banyuasri. E-Journal S1 Ak Universitas Pendidikan Ganesha, 3(1). Retrieved from https://ejournal.undiksha.ac.id/index.php/S1ak/article/view/4808.

Fauza, M. A., Saifi, M., \& Dwiatmanto. 2016. Analisis Sistem dan Prosedur Pemberian Kredit Modal Kerja guna Mendukung Pengendalian Kredit (Studi Kasus pada PT Bank Rakyat Indonesia (Persero) Tbk Cabang Kawi Malang). Jurnal Administrasi Bisnis, 39(1), 24-33. Retrieved from http://administrasibisnis.studentjournal.ub.ac.id/index.php/jab/article/view/ 1530.

Firdaus, R., \& Arianti, M. 2011. Manajemen Perkreditan Bank Umum. Bandung: Alfabeta.

Hindarto, A. E., AR, M. D., \& ZA, Z. 2014. Evaluasi Sistem Pemberian Kredit Modal Usaha dan Penerimaan Angsuran dalam Upaya Meningkatkan Efektivitas Pengendalian Intern (Studi Pada Kantor Pusat PD. BPR. Bank Jombang). $\quad 8(1), \quad 1-9 . \quad$ Retrieved from http://administrasibisnis.studentjournal.ub.ac.id/index.php/jab/article/view/ 330. 
Kasmir. 2015. Dasar-dasar Perbankan . Jakarta: Rajawali Pers.

Lestari, D. P., Darminto, \& Topowijono. 2013. Analisis Sistem dan Prosedur Pemberian Kredit Multiguna dalam Upaya Meningkatkan Pengendalian Kredit (Studi Pada PT. Bank Pembangunan Daerah Jawa Timur Cabang Madiun). Jurnal Administrasi Bisnis (JAB), 2(2), 82-92. Retrieved from http://administrasibisnis.studentjournal.ub.ac.id/index.php/jab/article/view/ 100.

Papalangi, R. S. 2013. Penerapan SPI dalam Menunjang Efektivitas Pemberian Kredit UKM pada PT. Bri (Persero) Tbk Manado. Jurnal Riset Ekonomi, Manajemen, Bisnis Dan Akuntansi, 1(3), 1212-1220. Retrieved from https://ejournal.unsrat.ac.id/index.php/emba/article/view/2528.

Putra, M. H. A., Rahayu, S. M., \& Saifi, M. 2016. Analisis Pengendalian Intern terhadap Sistem Pemberian Kredit Modal Kerja (Studi Kasus pada PT. Bank Perkreditan Rakyat UMKM Jawa Timur Cabang Pacitan). Jurnal Administrasi Bisnis, 39(1), 195-204. Retrieved from http://administrasibisnis.studentjournal.ub.ac.id/index.php/jab/article/view/ 1552.

Sa'adah, A., Dwiatmanto, \& Husaini, A. 2015. Analisis Sistem Pemberian Kredit Multiguna dalam Upaya Meningkatkan Pengendalian Kredit (Studi pada PT.Bank Jatim Tbk Cabang Lamongan). Jurnal Administrasi Bisnis (JAB), 22(2), 1-6. Retrieved from http://administrasibisnis.studentjournal.ub.ac.id/index.php/jab/article/view/ 887.

Salim, F. A. 2015. Analisis Penerapan Sitem Informasi Akuntansi Dalam Mendukung Pengendalian Internal Pemberian Kredit Pada Pt. Bank Bukopin Manado. Jurnal EMBA, 3(1), 1034-1043. Retrieved from https://ejournal.unsrat.ac.id/index.php/emba/article/view/7808.

Sandi, P. A., Dwiatmanto, \& A, Z. Z. 2015. Analisis Sistem dan Prosedur Pemberian Kredit Konsumtif dalam Upaya Mendukung Pengendalian Manajemen Kredit (Studi pada Koperasi Simpan Pinjam Tri Aji Mandiri Kota Kediri). Jurnal Administrasi Bisnis (JAB), 21(2), 1-9. Retrieved fromhttp://administrasibisnis.studentjournal.ub.ac.id/index.php/jab/article/ view/849.

Saputra, I. P. M., Zukhri, A., \& Indriyani, L. 2014. Sistem Pengendalian Intern Pemberian Kredit Pada Pt. Bpr Suryajaya Kubutambahan. 4(1). Retrieved fromhttps://ejournal.undiksha.ac.id/index.php/JJPE/article/view/2084/1817

Sesiady, N. A., AR, M. D., \& Saifi, M. 2018. Analisis Sistem dan Prosedur Pemberian Kredit Modal Kerja dalam Upaya Menudukung Pengendalian Intern (Studi Pada PT. BPR Nusamba Wlingi Cabang Kepanjen). Jurnal Administrasi Bisnis, 61(1), 181-190. Retrieved from http://administrasibisnis.studentjournal.ub.ac.id/index.php/jab/article/view/ $2561 / 2953$. 
Syafriansyah, M. 2015. Analisis Sistem dan Prosedur Pemberian Kredit pada Koperasi Simpan Pinjam Sentosa di Samarinda. Ilmu Administrasi Bisnis, 3(1), 83-93. Retrieved from http://ejournal.adbisnis.fisipunmul.ac.id/site/?p=969.

Tawaqal, I., Sudjana, N., \& Yaningwati, F. 2016. Evaluasi Sistem Pengendalian Intern stas Prosedur Pemberian Kredit, Pengeluaran dan Penerimaan Kas (Studi pada PT. Bank Perkreditan Rakyat Kawan Malang). Jurnal Administrasi Bisnis (JAB), 39(2), 100-106. Retrieved from http://administrasibisnis.studentjournal.ub.ac.id/index.php/jab/article/view/ 1565.

Topowijono, R. N. F., \& Azizah, D. F. 2015. Evaluasi Sistem dan Prosedur Pemberian Kredit Konsumtif dalam Upaya Mendukung Pengendalian Intern (Studi Kasus pada Koperasi Simpan Pinjam Bina Usaha Mandiri Kota Blitar). Jurnal Administrasi Bisnis (JAB), 26(2), 1-7. Retrieved from http://administrasibisnis.studentjournal.ub.ac.id/index.php/jab/article/view/ 1055 .

Undang-Undang Nomor 10 Tahun 1998 